Research Article

\title{
Synthesis of Goethite (a-FeOOH) Pigment by Precipitation Method from Iron Lathe Waste
}

\author{
Lilik Miftahul Khoiroh*, Elysia Dwi Nuraini, Nur Aini \\ Chemistry Department, Science and Technology Faculty, Universitas Islam Negeri Maulana Malik Ibrahim Malang, Malang, \\ Indonesia 65144
}

\section{ARTICLE INFO}

\section{Article History}

Revised 28 September 2018

Accepted 17 October 2018

Available online 30 December 2018

* Email of author corresponding:

lilikmfx@gmail.com

\section{ABSTRACT}

\begin{abstract}
Lathe waste contains high iron content potential to be further processed into goethite pigment. The purpose of the research was to determine the effect of synthesis temperature on the structure, colour values, and morphology of goethite pigment. The synthesis was conducted with temperature variations of $60,70,80$ and $90^{\circ} \mathrm{C}$. The XRD diffraction pattern shows that crystal structure of the product of all synthesis temperatures are goethite $(\mathrm{a}-\mathrm{Fe}-\mathrm{OOH})$ with orthorhombic structure. The crystal size of the pigment ranges between $11.17-12.32 \mathrm{~nm}$. Colour value analysis shows that product of $70^{\circ} \mathrm{C}$ synthesis temperature exhibits the highest lightness value about 40.5. Based on SEM-EDX imaging, the morphology of the samples is not uniform and forming agglomerates. Traces of impurities were detected, such as $\mathrm{C}$ and $\mathrm{Na}$.
\end{abstract}

Keywords: Iron lathe waste, goethite, temperature, precipitation

\section{Introduction}

Home lathe industry contributes in generating lathe waste of high iron content. One of the methods available to reduce iron content is by processing the waste into iron oxide pigment [1]. Nowadays, the interest on the production of iron oxide nanoparticle as pigment has increased considerably due to its advantageous properties such as non-toxicity, durability, relative inertness and various colors [2, 3, 4].

The world consumption of yellow pigment has reached 69,000 tons in 2015 and it continues to increase annually [5]. The highest consumption arises from its use as a widely applied colorant in construction products, paint, coating, animal feed, glass, ceramic and other uses [6]. Yellow iron oxide is composed of goethite $(\alpha-\mathrm{Fe}-\mathrm{OOH})$ with orthorhombic crystal system. The standard goethite exhibits color values as follows; $L^{*}$ ranges from 51 to $71, C^{*}$ from 41 to 61 and $H^{\circ}$ from 72 to 84. The colour of a pigment is affected by its structure, particle size and shape [7].

Several variables known to influence iron oxide synthesis including type of precursor [8, 9], temperature [10] and synthesis method [6] which will affect the structure, morphology, colour and particle size [11]. Legodi and de Waal succeeded producing goethite with mill scale precursor [8]. Muller et al. [12] carried out goethite synthesis at $60^{\circ} \mathrm{C}$ that resulted in goethite with particle size of $0.36 \mu \mathrm{m}$. Meanwhile, goethite synthesis at $70^{\circ} \mathrm{C}$ produced particle size around $0.318 \mu \mathrm{m}$ with octahedral structure. Bilalodin et al. [6] performed goethite synthesis by precipitation method, producing goethite $(\mathrm{Fe}-\mathrm{OOH})$ of orthorhombic structure with uniform shape about $0.35 \mu \mathrm{m}$ and the colour test result came out as $\mathrm{L}^{*}=$ $66.76, a^{*}=14.84, b^{*}=49.95[6]$. The aim of this research was to find out the effect of synthesis temperature on the structure, colour and morphology of product synthesized through precipitation method. 


\section{Materials and Methods}

\subsection{Materials}

The materials used in this experiment were lathe waste attained from an industry in Malang, $\mathrm{HNO}_{3}$ p.a (Merck), distilled water, $\mathrm{NaHCO}_{3}$ p.a (Merck), and $\mathrm{NaOH}$ p.a (Merck).

\subsection{Preparation of Goethite ( $\alpha-\mathrm{Fe}-\mathrm{OOH})$ with Temperature Variation}

Precursors were prepared by dissolving lathe waste in $\mathrm{HNO}_{3} 3.5 \mathrm{M}$. The mixtures were allowed to sit for 24 hours in order to completely dissolve and then heated to form paste [8]. Each precursor was subsequently dissolved in $250 \mathrm{~mL}$ of distilled water and added with $25 \mathrm{~mL}$ of $\mathrm{NaHCO}_{3} 0.5 \mathrm{M}$, the pH was adjusted to 6 . Afterwards, the solutions were heated with temperature variations of $60,70,80$ and $90^{\circ} \mathrm{C}$ for 1 hour and stirred using mechanical stirrer at $750 \mathrm{rpm}$. After precipitate of yellow iron oxide was obtained, it was rinsed several time using distilled water and then dried at room temperature.

\subsection{Characterization of Goethite Pigment}

Crystal structure of synthesized goethite pigment was characterized through powder X-Ray Diffraction using PAN Analytical Experiment Pro Type. Crystal size can then be calculated from X-Ray Diffraction data using Scherer equation. Pigment colour was measured with colour reader using Minolta CR-10. The morphology and composition of sample were analysed with scanning electron microscopy-energy dispersion spectroscopy (SEM-EDS) (EVO @ MA).

\section{Results and Discussion}

\subsection{X-Ray Diffraction}

The XRD pattern of goethite in Figure 1 shows low intensity peaks which indicate a low crystallinity. The peaks correspond with those of the orthorhombic phase of Fe-OOH (ICSD no. 159960). Based on the X-Ray diffraction pattern, temperature variation holds no significant effect to crystal structure. The highest peak is obtained at $2 \theta$ around $21^{\circ}$. This result is in compliance with that of Muller and Garcia, which reported goethite exhibits highest peak intensity at $2 \theta\left(21^{\circ}\right)$ $[10,12]$. The difference on the diffraction pattern was observed on the products of $60^{\circ} \mathrm{C}$ and $90^{\circ} \mathrm{C}$ synthesis temperature, which display a smaller slight shift towards $2 \theta$, compared to that synthesized at $70^{\circ} \mathrm{C}$ and $80^{\circ} \mathrm{C}$ with a larger slight shift towards $2 \theta$. This $2 \theta$ shifts are possibly due to shifting parameters of crystal lattice cells and some types of defects in goethite crystal lattices [9]. Refinement result of goethite shows unit cell dimensions match with those of standard $a=9.9450(\AA), b$ $=3.0268(\AA), c=4.6101(\AA)$ (Table 1). Based on refinement data, products of all temperature variations have Rp, Rwp, and $x^{2}$ value $<4 \%$.

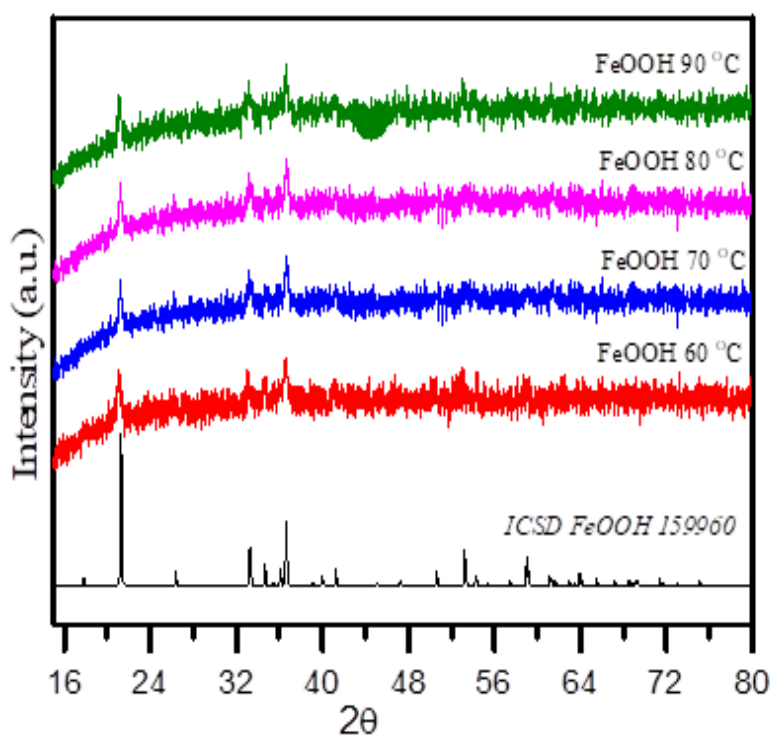

Figure 1. X-ray Diffraction pattern of Goethite with Variation in Synthesis Temperature

The determination of crystallite size of goethite was carried out based on the line broadening in x-ray diffraction and calculated with Debye- Scherer equation displayed in Table 2. The crystal size of goethite obtained at synthesis temperature 
of $70^{\circ} \mathrm{C}$ exhibits largest crystal size $(12.32 \mathrm{~nm})$ among the others, whereas the smallest crystal size addressed to goethite of $80^{\circ} \mathrm{C}$ synthesis temperature $(11.17 \mathrm{~nm})$. The crystal size of the product obtained ranges from 11-12 nm.

Table 1. Crystallographic Data of Product

\begin{tabular}{|c|c|c|c|c|c|}
\hline \multirow{2}{*}{ Compound } & \multirow{2}{*}{ Crystallographic system } & \multirow{2}{*}{ Z } & \multicolumn{3}{|c|}{ Unit Cell Dimensions $(\dot{A})$} \\
\hline & & & $\mathbf{a}$ & b & c \\
\hline Goethite $60^{\circ} \mathrm{C}$ & Orthorhombic & 4 & 9.936939 & 3.016905 & 4.610142 \\
\hline Goethite $70^{\circ} \mathrm{C}$ & Orthorhombic & 4 & 9.958837 & 3.027141 & 4.407518 \\
\hline Goethite $80^{\circ} \mathrm{C}$ & Orthorhombic & 4 & 9.934693 & 3.018082 & 3.018082 \\
\hline Goethite $90^{\circ} \mathrm{C}$ & Orthorhombic & 4 & 9.965591 & 3.027335 & 4.610007 \\
\hline
\end{tabular}

Table 2. Crystallite Size of Product

\begin{tabular}{ccc}
\hline Goethite & hkl & Crystallite size $(\mathbf{n m})$ \\
\hline $60^{\circ} \mathrm{C}$ & 101 & 11.49 \\
$70^{\circ} \mathrm{C}$ & 101 & 12.32 \\
$80^{\circ} \mathrm{C}$ & 101 & 11.17 \\
$90^{\circ} \mathrm{C}$ & 101 & 11.97 \\
\hline
\end{tabular}
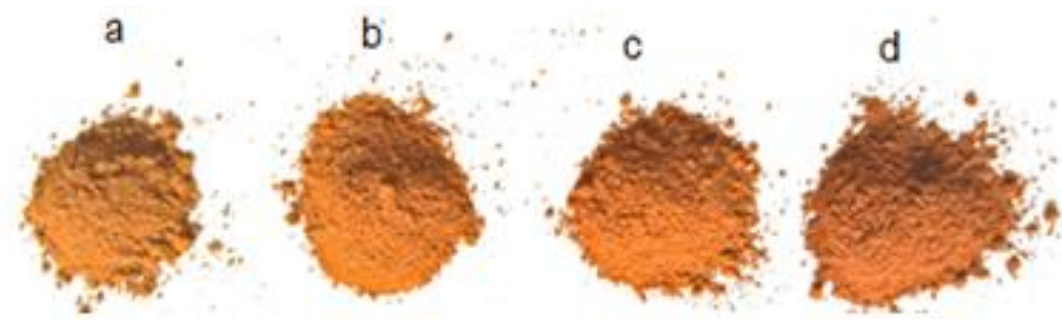

Figure 2. Goethite obtained at (a) $60^{\circ} \mathrm{C}$ (b) $70^{\circ} \mathrm{C}$ (c) $80^{\circ} \mathrm{C}$ (d) $90^{\circ} \mathrm{C}$ of synthesis temperature

\subsection{Color Reader}

Figure 2 shows the colour of the obtained goethite pigment which is yellowish and turns darker with the increase in synthesis temperature. The colour of product at $90^{\circ} \mathrm{C}$ synthesis temperature is redder, as in the Muller's research which was obtained at identical synthesis temperature using $\mathrm{Fe}\left(\mathrm{NO}_{3}\right)_{3}$ precursor, producing pigment of red colour which indicates the presence of impurities hematite [12]. The difference in pigment colour is accounted to the presence of impurities [12], particle structure and particle size [7]. Smaller size of crystal results in more reddish pigment colour. The highest crystal size in this study was attained at $70^{\circ} \mathrm{C}$ synthesis temperature, influenced by the value of $b^{*}$ which leads to the highest lightness among the others (Figure $3(a)$ ). Based on Figure $3(b)$, the pigment exhibits yellow colour values. According to the value of $a^{*}$ (green-red) and $b^{*}$ (blueness-yellow) data, the highest $b^{*}$ value retained by the product of $70^{\circ} \mathrm{C}$ synthesis temperature, indicating it has more yellow colour properties than the others.
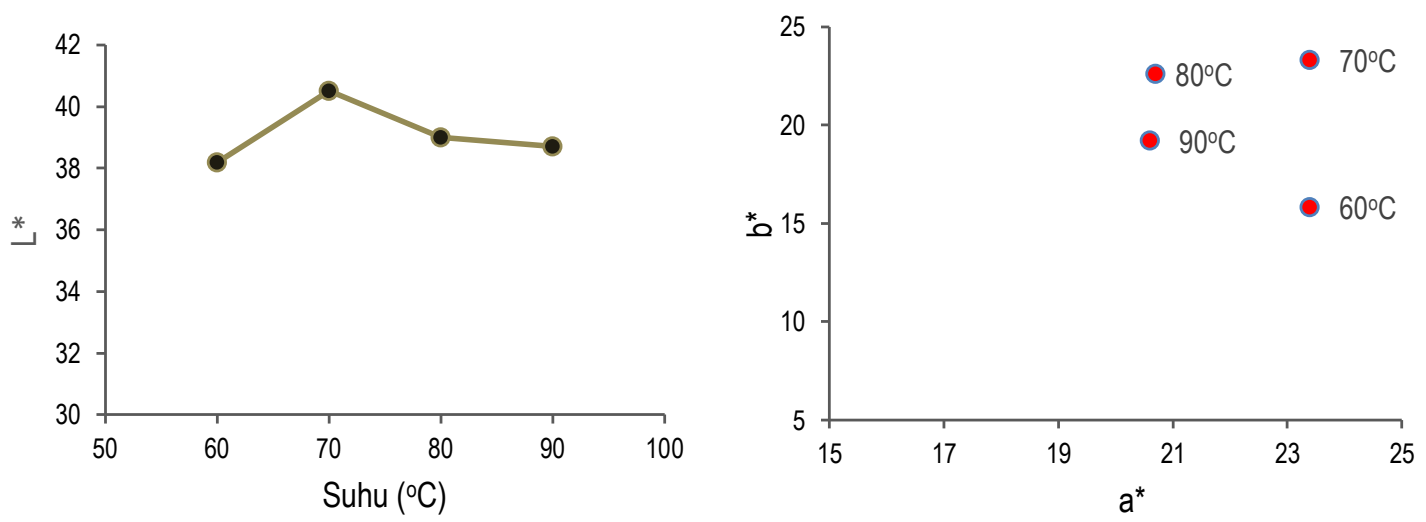

Figure 3. (a) Lightness level of the product and (b) Value $a^{*} b^{*}$ of the products 
Figure 4 shows that the hue and chroma or colour intensity of product of all temperature variations does not exhibit significant difference, except for the product of $60^{\circ} \mathrm{C}$ synthesis temperature. The colour value of the products is out of range of standard goethite. The colour coordinates of pigment tend to be dark. The values of $\mathrm{L}^{*}, \mathrm{C}^{*}, \mathrm{H}^{\circ}, \mathrm{a}^{*}, \mathrm{~b}^{*}$ of product of all temperature variations are not in accordance with those of standard, indicating the presence of impurities. It is most likely caused by the precursor used in the synthesis process was originated from lathe waste which possibly contains other metals.

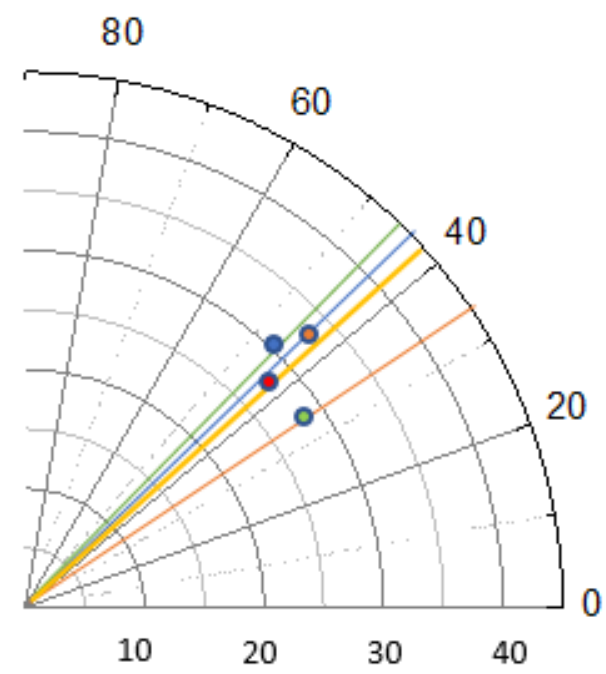

Figure 4. Chroma and Hue of products of $660^{\circ} \mathrm{C}, 70^{\circ} \mathrm{C}, 080^{\circ} \mathrm{C}$ and $990^{\circ} \mathrm{C}$ synthesis temperature

\subsection{SEM-EDX}

Based on the SEM data (Figure 5), the morphology of the product is agglomerates and ununiform. The agglomeration of product will affect pigment colour, turning it dark. According to Cornell and Schwertmann [7], particle shape influences the orientation of particles to incident light as absorption spectrum and the crystallographic orientation affecting pigment colour. The composition of the product indicates high iron and oxygen content with traces of impurities such as $\mathrm{Na}$ and $\mathrm{C}$ (Table 3). The impurities presumably come from the use of $\mathrm{NaHCO}_{3}$ which is a precipitation agent used in synthesis process.

Table 3. Elemental Composition of the Pigment

\begin{tabular}{lccccc}
\hline Element & $\mathrm{Fe}$ & $\mathbf{0}$ & $\mathbf{C}$ & $\mathrm{Na}$ & Total \\
Content & $44.54 \%$ & $40.65 \%$ & $5.77 \%$ & $0.97 \%$ & $100 \%$ \\
\hline
\end{tabular}

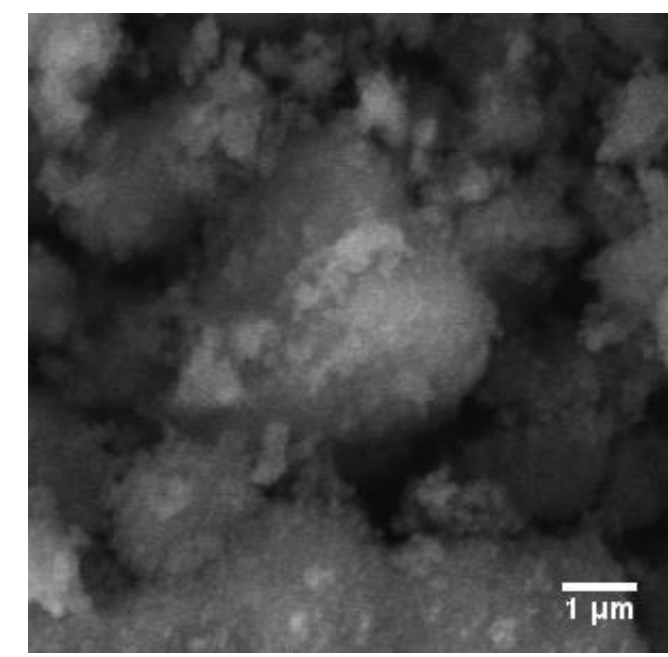

Figure 5. SEM result of goethite synthesized at $60^{\circ} \mathrm{C}(6000 \mathrm{x}$ magnification) 


\section{Conclusion}

Goethite synthesis from lathe waste was conceivable to carry out through precipitation method. Crystal structure of the products of all temperature variations is orthorhombic with nanocrystal size. The colour value of the pigment is out of range of the standard goethite pigment. The morphology of the product is not uniform and forming agglomerates. Pigment composition indicates the presence of impurities such as $\mathrm{Na}$ and $\mathrm{C}$.

\section{References}

[1] S. R. Prim, M. V. Folgueras, M. A. de lima, \& D. Hotza, "Synthesis and Characterization of Hematite Pigment Obtained from a Steel Waste Industry," Journal of Hazardous Materials, vol. 191, no. 3, pp. 1307 -1312, 2011.

[2] M. P. Aji, A. Yulianto, \& S. Bijaksana, "Sintesis Nano Partikel Magnetit, Maghemit dan Hematit dari Bahan Lokal," Jurnal Sains Materi Indonesia, pp. 106-108, 2007.

[3] M. Mohapatra \& S. Anand, "Synthesis and Applications of Nano-Structured Iron Oxides/Hydroxides," International Journal of Engineering, Science and Technology, vol. 2, no. 8, pp. 127-146, 2010.

[4] T. A. Kusumawati, "Sintesis Nanopartikel Pigmen Oksida Besi Hitam $\left(\mathrm{Fe}_{3} \mathrm{O}_{4}\right)$, Merah $\left(\mathrm{Fe}_{2} \mathrm{O}_{3}\right)$ dan $\mathrm{Kuning}(\mathrm{FeOOH})$ Berbasis Pasir Besi Tulungagung," Minor Thesis, Universitas Negeri Malang, Malang, 2013.

[5] A. O. Tanner, "Iron Oxide Pigment (Advance Release)", U.S Geological Survey Mineral Yearbook, Dec., pp. 40.140.8, 2015.

[6] Bilalodin, Z, Irayani, Sehah, \& Sugito, "Sintesis dan Karakterisasi Pigmen Warna Hitam, Merah dan Kuning Berbahan Dasar Pasir Besi," Molekul, vol. 10, no. 2, pp. 2015.

[7] R. M. Cornell \& U. Schwertmann, The Iron Oxide: Structure, Properties, Reactions, Occurrences and Uses, $2^{\text {nd }}$ Ed. Weinheim: Wiley-VCH Verlag GmbH \& Co. KGaA, 2003.

[8] M. A. Legodi \& D. de Waal, "The Preparation of Magnetite, Geothite, Hematite and Maghemite of Pigment Quality from Mill Scale Iron Waste," Dyes and Pigments, vol. 74, no. 1, pp. 161-168, 2007.

[9] T. P. Rahman, A. Sukarto, N. T. Rochman, \& A. Manaf, "Sintesis Pigmen Besi Oksida Berbahan Baku Limbah Industri Baja (Mill Scale)," Jurnal Fisika, vol. 3, no. 1, pp. 86-89, 2013.

[10] M. Villacís-García, M. Ugalde-Arzate, K. Vaca-Escobar, M. Villalobos, R. Zanella, \& N. Martínez-Villegas, "Laboratory Synthesis of Goethite and Ferrihydrite of Controlled Particle Sizes," Boletin De La Sociedad geologica Mexicana, vol. 67, no. 3, pp. 433-446, 2015.

[11] E. Wetterskog, M. Agthe, A. Mayence, J. Grins, D. Wang, S. Rana, A. Ahniyaz, G. Salazar-Alvarez, \& L. Bergstrom, "Precise Control Over Shape and Size of Iron Oxide Nanocrystals Suitable for Assembly into Ordered Particle Arrays," Science and Technology of Advanced Materials, vol. 15, no. 5, 2014.

[12] M. Müller, J. C. Villalba, F. Q. Mariani, M. Dalpasquale, M. Z. Lemos, M. F. G. Huila, \& F. J. Anaissi, "Synthesis and Characterization of Iron Oxide Pigments through the Method of the Forced Hydrolysis of Inorganic Salts," Dyes and Pigments, vol. 120, pp. 271-278, 2015. 